\title{
The Tragic perspective in Hamlet's character during the play-scene
}

\author{
Malik Hashim Hassan
}

\author{
Ministry of education, Education General directorate in Thiqar, Iraq \\ alidakhil2016@gmail.com
}

\begin{abstract}
The researcher explains the tragic of the play represented with Hamlet's father death. The most familiar image of the play is the young prince contemplating how he will revenge., the overriding theme being how people react to death. Though every version has the basic central story of Hamlet's revenge for his father's murder, each inevitably presents a more or less subtly different narrative, some omitting whole scenes and even major story threads. All this helps to explain why the play - and its central character-have been subject to an exceptionally wide range of interpretation. The researcher in this paper, will concentrate on one of the tragic situation for the protagonist of the play that father's murder by his mother and uncle.
\end{abstract}

Keywords-Hamlet's character, play-scene.

\section{INTRODUCTION}

Although this play is over four hundred years old, the conflicts of these characters are still relevant today. Hamlet is uncertainly the most well-known play in the English language. it is written Probably in 1601 or 1602, Hamlet's tragedy is one of Shakespeare's masterpiece. the playwright achieved artistic maturity in this work via his brilliant depiction of the protagonist's conflict with two opposing forces: moral integrity and the need to revenge his father's murder. Shakespeare's focus on this struggle was a different from contemporary revenge tragedies, which tended to graphically dramatize violent acts on stage, by emphasizing the hero's dilemma rather than actually showing the bloody deeds.

The protagonist must be an admirable but

flawed character, with the audience able to understand and sympathize with the character. Certainly, all of

Shakespeare's tragic protagonists are capable of both good and evil.

(Hamlet as A Tragedy,2011)

Shakespeare established Hamlet from several resources, creating a rich and complicate literary work that stills to delight both readers and audiences with its several meanings and interpretations. Ernest Johnson said the problem of Hamlet is to understand himself from the seduction to wreak justice for the wrong reasons and in evil passion, and to do what he must do at last for the pure sake of justice and from that dilemma of wrong feelings and right actions, he ultimately emerges, solving the problem by attaining a proper state of mind. Hamlet endures as the object of universal identification because his central moral dilemma transcends the Elizabethan period, making him a man for all ages. In his difficult struggle to somehow act within a corrupt world and yet maintain his moral integrity, Hamlet ultimately reflects the fate of all human beings, even in this day and age.

In fact, Hamlet's tragedy is one of Shakespeare's greatest tragedies:

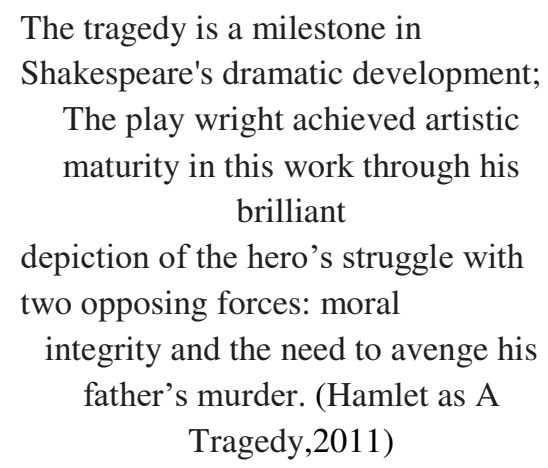

Hamlet, is one of the great tragedies in the literature world. It is the first tragedy in Shakespeare's series which is believed to be published in between 1601 and 1603. This play is a successful, perfect of Shakespeare's plays and best plays ever known. Hamlet focuses on the troubles arising from betrayal, love, and death without offering the audience a decisive and positive resolution to these complications for Hamlet himself is ambiguous and the answers to these problems are complex Shakespearean tragedies and It provokes the suffering to the hero. The supernatural elements in the dramas of Shakespeare are subservient to the main action. It provokes the protagonist to do certain actions. Shakespeare links the supernatural 
elements with the natural. Hamartia leads the downfall of the characters in Shakespearean plays.

Shakespeare would have taken Hamlet's story from several potential sources, including a twelfth-century Latin history of Denmark, a prose work by the French writer and Thomas Kyd's Ur-Hamlet. It was a common tradition during the sixteenth and seventeenth centuries to borrow ideas and stories from earlier literary works. The tragic act for the protagonist when Hamlet's uncle murders the prince's father, marries his mother and claims the throne. At the first time, Hamlet, the prince of Denmark, pretends to be weak to throw his uncle off guard, then he manages to kill his uncle and take the revenge for his father's murder. But, Shakespearean version varies making his Hamlet a philosophical-minded prince who delays taking action because his knowledge of his uncle's crime is so uncertain.

Shakespearean Hamlet can be studied as a Revenge play influenced by Seneca, the father of this genre. Shakespeare has revived the Senecan tragedy, in this sense, it is a Renaissance play. Here, Shakespeare uses the scene of violence, killing, murdering and bloodshed as Seneca used in his tragedy to satisfy the need of Elizabethan audiences. This revival made it Renaissance play. As a Renaissance character, Hamlet is suffering from the hangover between the medieval belief of superstition and reason, the belief of Renaissance. But, as a Renaissance student, he doubts on the appearance of the ghost. Hanging on the verge of scientific and superstitious belief is one of the features of Renaissance man. He doubts on the ghosts and thinks that it may be devil attempts to lure him to the crime. As a Renaissance character, Hamlet feels deeply and watches others to see what their feelings are. As a student of psychology, he experiments the crime through the similar story that matches to his father's killing. He wants to take revenge against his uncle when the crime is identified. And man centered philosophy of the Renaissance could be seen in the figure of Hamlet. (Hamlet as A Tragedy,2011)

This article explains an exploration of Hamlet's crisis as a tragic hero. Hamlet is the son of the recently deceased King Hamlet and the protagonist of the play. He returns to Denmark from his University of Wittenberg in England in the wake of his father's death. He is disgusted by his mother Gertrude's marriage to his uncle Claudius, which happened after his father's murder in short time. Hamlet expresses his father and even before knowing of his murder. He mourns in what others view as excessive. He is educated, embosoming, and tend to overthinking. Shakespeare uses soliloquies to decrease other characters and express moral facts and externalize internal struggles.
Hamlet's ghost provides the abetting incident for the play by charging his son with the task of taking revenge on Claudius. The ghost tells Hamlet that he cannot move on to heaven until his revenge of most unnatural murder and foul crime. Hamlet is skeptical of the ghost at first, wondering whether it is truly the ghost of his father or an instrument of evil that has come to tempt him to commit sin. However, Hamlet already loathes Claudius, so when he uncovers evidence of Claudius's guilt, Hamlet believes the ghost and embarks on the course of revenge.

\section{RESEARCH METHODOLOGY}

During of Marxist theory and of Bakhtin's principles of the Carnival, this paper emphasizes that Claudius and Hamlet mix themselves with carnivalesque masks but that Hamlet has an advantageous "understanding of the corrosive and clarifying power of laughter" (Brooks,1991. p.350). Claudius appears and in his first speaks of a festive commingling between marriage and death, but he only appropriates carnivalesque themes and values "in order to make legitimate his own questionable authority" (p.355). One of his Ironies, his means of securing the crown "typically mocks and uncrowns all authority" (p.356). Although Hamlet initially refuses festivities, his killing of Polonius marks the change in him. Hamlet's use of grotesque Carnival equivocation in the scene with the King, his father/mother, suggests Hamlet's development (p.358). Hamlet's interaction with "actual representatives of the unprivileged"(p.358) the Gravediggers completes Hamlet's training in carnivalism (p.359). Aside from the "clear and explicit critique of the basis for social hierarchy" (p.360), this scene explains Hamlet reflecting on death, body identity and society. Now Hamlet is ready to participate in the final festival of his uncle that is the duel. True to the carnival tendencies, the play ends with "violent social protest" and "a change in the political order" (p.364).

From the moment, Hamlet faces his father's spirit and he is suffocated by his consuming insecurities and consistently throughout the play from that point on. Hamlet is sure of in one scene, he doubts in the next. Hamlet knows that it is the spirit of his father on the castle wall. Then, he understands fully its unmistakable cry for revenge. But, when he is alone, Hamlet rejects what he has witnessed in a maelstrom of doubt and fear:

The spirit that I have seen

May be the devil; and the devil hath power

To assume a pleasing shape; yea, and perhaps

Out of my weakness, and my melancholy, 
As he is very potent with such spirits,

Abuses me to damn me. (Kenneth,1973)

As Kenneth Muir points out in Shakespeare and the Tragic Pattern: Shakespeare's testament to real life is the emphasis on ambiguity in the play, and the absence of overt instruction on how to overcome such ambiguity is. Every one of us has experienced Hamlet's conflicts to find the truth in a mire of delusion and uncertainty, often to no avail. [Hamlet] has to work out his own

salvation in fear and trembling; he has to make a moral decision,

in a complex situation where he cannot rely on cut-and-dried moral

principles, or on the conventional code of the society in which he lives;

and on his choice depend the fate of the people he loves and the fate of the kingdom

to which he is the rightful heir. (Kenneth ,1973. p.154)

Hamlet also can be sub-divided as a revenge play and this type was a popular in the Elizabethan and Jacobean periods. Elements common to all revenge tragedy include: First, a hero who must avenge an evil deed, often encouraged by the apparition of a close friend or relative; Secondly, scenes of death and mutilation; Thirdly, insanity or feigned insanity; Fourthly, sub-plays; and Finally, the violent death of the hero. Seneca, the Roman poet and philosopher, is accepted to be the father of such revenge tragedy, and a tremendous influence on Shakespeare. Thomas Kyd's Spanish Tragedy, written in 1592, is credited with reviving the Senecan revenge drama as well as spawning many other plays, such as Marlowe's The Jew of Malta, Webster's The Duchess of Malfi, the Ur-Hamlet and Shakespeare's own Titus Andronicus, in addition to Hamlet. (Amanda,2000)

\section{REVENGE IN HAMLET}

There are three plots in Shakespeare's Hamlet: the main revenge plot and two sub-plots involving the romance love between Hamlet and Ophelia and the looming war with Norway. The sketch of the main plot through Hamlet's journey for vengeance a look at all the significant events on this play mentions a summary of some of it:

\subsection{Introduction to the Elizabethan Revenge Tragedy}

Thomas Kyd established the revenge tragedy with his wildly popular Spanish Tragedy (1587), and Shakespeare perfected the genre with Hamlet, which is likely based on another revenge play by Kyd called the Ur-Hamlet. Sadly, no copy of Kyd's Ur-Hamlet exists today.Most of the revenge tragedies share some main factors: a play within a play, mad scenes, a vengeful ghost, one or several gory scenes, and, most importantly, a central character who has a serious grievance against a formidable opponent. This central character takes matters into his own hands and seeks revenge privately. It should be noted that Hamlet is the only protagonist in any Elizabethan revenge play who can be considered a hero, aware of the moral implications involved in exacting his revenge.

The Elizabethan Period was one of the most important eras in the European history. It can be defined as the epoch in English history marked by the reign of Queen Elizabeth I (1558-1603). Historians often depict it as the golden age in English history. "The symbol of Britannia was first used in 1572, and often thereafter, to mark the Elizabethan age as a renaissance that inspired national pride through classical ideals, international expansion, and naval triumph over the Spanish — at the time, a rival kingdom much hated by the people of the land." (Dakhil,2018) In this change of the whole life field, the historian John Guy (1988) expressed the situation at this time in England as " England was economically healthier, more expansive, and more optimistic under the Tudors" than at any time in a thousand years. (Dakhil,2018).

Shakespeare in his masterpiece 'Hamlet' embodied obviously the Elizabethan period superstitions phenomena. He employed the ghost as the rising point of the play and showed it as the main motive for the whole events. Also, through the ghost Shakespeare was able to make the picture clear for the reader about the beliefs and doctrines at the time of Queen Elizabeth 1. He uses a well convincing plot to turn the play to a historical story which can fit all the ages and centuries. The modern reader can easily indulge and interact with the events. Also, he pointed out the prevailing belief at that time which related to omens and how people believe in these omens to the extent they relate all what will happen in their life to certain accidents such as show up of ghosts, the dead people walk at the roads, comets fall from the sky, eclipse, etc. People were analyzing the coming situations according to their reading to the superstitions they have seen. Shakespeare creates terrifying effect on the readers when he employed the appearance of the ghost in the opening scene." Critics are almost unanimous in praising the subtle means by which Shakespeare has produced an atmosphere of supernatural mystery and fear" (Dakhil,2018).

\subsection{The play within play in Hamlet}

It cannot assign the 'Murder of Gonzago as a high literary value ,' but it seems to be a fair sample of the drama of the 'Cambises' variety. This variety which must have fallen upon the ears of Shakespeare's audience as 
stilted and artificial. of course. There is a reason for the employment of this sort of drama just here. Shakespeare "had to distinguish the style of the speech from that of his own dramatic dialogue." Although The death of Gonzago was not of a type unknown to the audience of the Globe Theater, it would have seemed old-fashioned on account of its conventionality, its monotonous rhymes, and its rather turgid rhetoric. All this, with the antiquated dumb-show, set sharply against the prose of the speeches of Hamlet, Ophelia, and the King, would have increased its illusion as a stage stage-play.(Lawrence, 2013)

Hamlet's discussion with the first Player and his instructions to the players, and in his words to Horatio before the play made the close resemblance between the play and the murder more logic. In addition to that, it focusses the interest of the audience upon the spoken play. This action because of Hamlet's exultant words to Horatio after the play is over, when his test of the King's guilt has fully succeeded.

Ham. O good Horatio, I'll take the ghost's word for a thousand pound. Didst perceive?

Hot. Very well, my lord.

Ham. Upon the talk of the poisoning?

Hot. I did very well note him.(Lawrence, 2013)

This fits well with demand of Hamlet before the play that Horatio will accurately observe the behavior of the King, and he will see if "his occulted guilt do not itself unkennel in one speech."(Lawrence, 2013). But the researcher here does not believe that Shakespeare felt it essential for his audience to determine the inducted speech. Since this evidence comes after the play. No dramatic purpose would be served by such knowledge. On the other hand, the interest is heightened if the audience is kept wondering which the assassin oration is to be and observing. Horatio, who has not been told which speech it is, for the king's self-betrayal. It is not a matter of consequence, and perhaps cannot be determined, whether the preparations of Hamlet involved also changing of the action. Shakespeare twice alerts the audience through the mouth of Hamlet that the action of the play is to be strikingly like that of the murder. When Hamlet is putting his plan.

later, after his first confession of intention to make use of the murder of Gonzago , he thinks:

I'll have these players

Play something like the murder of my father.

And still later, in his words to Horatio,

There is a play tonight before the king;

One scene of it conies near the circumstance

Which I have told thee of my father's death. (Lawrence, 2013)
So no tensile is enjoined upon the audience credulity, after all Hamlet's preparation, to look for the event of the play and of the show of this play within play represents the murder. in reality, Hamlet amended the event by inserting the detail of the poison in the ears. Claudius and Gertrude know that Hamlet was supervising the performance of the play. Hamlet wrote the oration of the play and training all the actors that the play was of his own choice.

In reality, Shakespeare has been somewhat more careful here than is his habituated that frequently asks his audience to swallow very large coincidences for the sake of significant effect. This presents as Claudius committed the killing a king with an apparently devoted wife is murdered while asleep in his garden by a relative who pours poison in his ears. Then, he gains the love of the queen.

To sum up, the 'play-within-play' has huge dramatic significance. It emphasizes the true that Hamlet is not the protagonist of a traditional revenge play because of his fails to kill the king at prayer on moral reasons even after getting confirmed of his sin by the play-scene of The Murder of Gonzago. "Play within play" is necessary that brings Claudius and Hamlet to a full awareness of each other's true nature. In addition to that, the "play-withinplay" helps Shakespeare to discover his own theories of play-acting.

A bloody deed! almost as bad, good mother,

As kill a king, and marry with his brother.

(English, Breaking News.2017)

\subsection{The real tragedy}

Hamlet's failure caused to find a strong reason for his stalemate has stopped critics from their own explanations. One of these critics is A.C. Bradley who identified the prince in his famous influential study "Shakespearean Tragedy" as afflicted by the shape of depression called melancholy in Shakespeare's day. On the other hand, Ernest Jones who proved classic of Freudian reading in both plays Hamlet and Oedipus. Hamlet's hesitation to revenge his father comes according to his repressed desire by killing his mother's lover and her new husband Claudius.

What is the mistake with all these tries to interpret for Hamlet's delay including Hamlet's own estimates is the same basic misunderstanding? All of them accept the idea that the prince has a religious commitment to revenge his father's murder and thus restore the status quo. Hamlet's problem that the murderer is the king himself who has the sovereign. So, the tragedy of the status considered Hamlet's unfortunate possession of some intellectual, emotional or psychological fault. however, Hamlet has a 
virtuous its pedigreed which prevents him from achieving that commitment without delay. (Ryan,2016)

\section{LITERATURE REVIEW}

Critics who consider inevitably Hamlet's hesitation to revenge as a source of limitless bafflement and made this tragedy 'the most problematic play ever written by Shakespeare or any other playwright. The researcher will explain two critics whom wrote about Shakespeare's Hamlet, they are:

\subsection{Leo Tolstoy}

The most famous critics was War and Peace, the novelist Leo Tolstoy, whose non-fiction work includes about one hundred pages' critique of Shakespeare's plays and his repute as a writer. Tolstoy in the work "Shakespeare and Drama in 1906", described Shakespeare's plays "trivial and positively bad," described also his enduring popularity "pernicious". Shakespeare refused himself as "an insignificant, inartistic writer" who was "not only not moral, but immoral." He also mentioned reading King Lear, Romeo and Juliet, Hamlet, and Macbeth ("works regarded as his best") for the first time in his youth, but recalled feeling nothing more than "an irresistible repulsion and tedium.", he concluded:

"I have felt, with even greater force, the same feelings - this time, however, not of bewilderment,

but of firm, indubitable conviction that the unquestionable glory of

a great genius, which Shakespeare enjoys and which compels writers of our time to

imitate him and readers and spectators to discover in him non-existent merits

thereby distorting their aesthetic and ethical

understanding) — is a great evil,

as is every untruth. (Anthony,2015).

\subsection{Voltaire}

Shaw's letter talks about the critical ideas for Voltaire, the French writer, whose criticisms of Shakespeare are the more noteworthy. Shaw showed that "because Voltaire began with an extravagant admiration for Shakespeare, and got more and more bitter against him as he grew older and less disposed to accept artistic merit as a cover for philosophic deficiencies." (Anthony,2015). During his exiled in Britain in the 1720 s, Voltaire won a serious interest in and appreciation for Shakespeare who at the time was unknown on the continent. He even went on to adapt a number of Shakespeare's works for French theater, among them La Mort de César (based on
Julius Caesar, 1731), Zaïre (based on Othello, 1733), and Sémiramis (based on Hamlet, 1748). Although Shaw's opinion of view, Shakespeare somewhat mellowed as his own reputation as a playwright. Later prints of Tolstoy's article even consisted a letter written by Shaw to its publishers, in which he wrote:

"I have striven hard to open English eyes to the emptiness of Shakespeare's philosophy, to the superficiality and second-handedness of his morality, to his weakness and incoherence as a thinker, to his snobbery, his vulgar prejudices, his ignorance, his disqualifications of all sorts for the philosophic eminence claimed for him." (Anthony,2015).

\section{CONCLUSION}

The analysis offered in this study is entirely in keeping with what may be called the traditional point of view of the play as expressed by the best critics of the present day. The lover of 'Hamlet' is not asked to accept a new and startling hypothesis which will totally change the significance of the piece; he is invited rather to consider Shakespeare's art in the management of detail. Surely the main lines of the action are simple and definite, and have been accepted as such by generations of playgoers. Shakespeare did not obscure the story so that it has been misunderstood for three hundred years. There is every indication, however, that he labored over 'Hamlet' more than was his wont, spending loving care on the nice adjustment of the smaller issues.The researcher endeavored to perceive his purpose in this study. surely, the researcher focuses not on the effect of blunting the poignancy of the tragedy or of diminishing its imaginative appeal. On the contrary, this study should leave us with a new admiration for Shakespeare's technical accomplishment, and a saner and discriminating enjoyment of his greatest masterpiece.

\section{REFERENCES}

[1] Amanda. M. (2000). Introduction to Hamlet. Shakespeare Online. Retrieved from: <http://www.shakespeareonline.com/plays/hamlet/hamletintroduction.html" $>$.

[2] Anthony. P (2015). Five Writers Who Really Hated Shakespeare. Retrieved from:https://www.mentalfloss.com/article/70783/5-writerswho-really-hated-shakespeare

[3] Brooks. J. R. (1991). Hamlet and Ophelia as Lovers: Some Interpretations on Page and Stage. Aligorh Critical Miscellany 4.1 (1991): 1-25.

[4] Dakhil. A. (2018). Hesitation in Shakespeare's Hamlet. Iraq. Darasat Tarbawiyah. Retrieved from: https://www.iasj.net > iasj 
[5] English, Breaking News. (2017). Discuss how the playwithin-play contributes to the development of action in Hamlet. Retrieved from:https://englitguidebd.blogspot.com/2017/08/examinerelationship-between-miranda.html

[6] Hamlet as A Tragedy. (2011) e-Notes Editorial. Retrieved from: https://www.enotes.com/homework-help/discusshamlet-by-shakespeare-tragedy-about-550-269390.

Accessed 9 Nov. 2019.

[7] Kenneth. M. (1973). Shakespeare and the Tragic Pattern. London: Folcroft Library Editions,

[8] Lawrence. W. (2013). The Play Scene in Hamlet. The Journal of English and Germanic Philology. Vol.18. 1 Jan. 1919. Shakespeare Online. Retrieved from: < http://www.shakespeareonline.com/plays/hamlet/spokenplayhamlet.html >.

[9] Ryan. K (2016). Hamlet and Revenge. British Liberty Journal. Retrieved from :https://www.bl.uk/shakespeare/articles/hamlet-andrevenge 